\title{
Reviews
}

\section{New Book Chronicle}

\section{Robert Witcher}

Migration is rarely out of the news, and the movement of people has become one of the most politically charged issues of the day. At the time of writing, Pope Francis is embroiled in a spat with presidential hopeful Donald Trump over the issue of Mexican migration to the USA, attempts to restrict the free movement of European citizens underlie much of the discussion of the forthcoming UK referendum and refugees continue to flee war-torn Syria. In such a context, the symbolism of Neil MacGregor's choice for his final curatorial acquisition for the British Museum is potent: a cross fashioned from wood salvaged from a migrant ship wrecked on the island of Lampedusa.

How have archaeologists dealt with migration, and can archaeology provide any long-term perspective? Migration is hardly a novel topic for archaeologists. Indeed, its heyday was during the early twentieth century, before it slipped from the archaeological literature in the aftermath of the Second World War-contaminated by the complicity of some archaeologists with nationalist agendas-to be replaced for half a century with discussion of the movement of objects and ideas. Well, now migration is back-if, indeed, it really did go away. This revival seems to be the result of the new methods now available, such as isotopes and aDNA, new questions stimulated by the increased flows of migrants in the global present, and a renewed sense of purpose to connect with wider societal concerns. The books reviewed here all tackle, explicitly or implicitly, questions about migration in the past and, in some cases, in the present too.

\section{People on the move}

BRenda J. Baker \& TAKeyuki Tsuda (ed.). Migration and disruptions: toward a unifying theory of ancient and contemporary migrations. 2015. xiii 348 pages, 26 b\&w illustrations, 6 tables. Gainesville: University Press of Florida; 978-0-8130-6080-4 hardback $\$ 84.95$.

Given the circumstances outlined above, a book with the title Migration and disruptions catches the eye, and consideration of the resonance between the 'ancient and contemporary

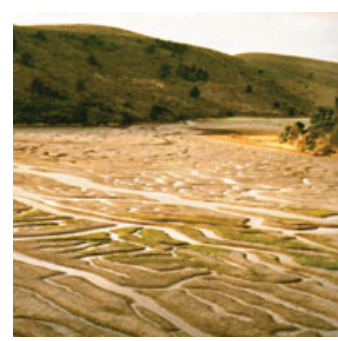
migrations' of its subtitle seems timely. The remainder of the book's title, however-'toward a unifying theory'sounds something of a throwback. And come to think of it, why 'disruptions'? Inside, the mystery deepens. The volume derives from an interdisciplinary workshop based at Arizona State University (ASU) to explore population movement throughout human history. The aims, outlined by the editors, BRENDA BAKER and TAKEYUKI TsUdA, are of the broadest relevance: "To what extent have environmental and social disruptions been a cause of migration over time?" and "Did migratory flows lead to disruptive consequences for the societies that received them?" (p. 5). There is that word again: disruption. Why not simply environmental and social 'factors' leading to 'change'? As if alert to the hackles rising on the reader's back, the editors explain that 'disruption' need not have negative connotations. But these are difficult to shake off. Disruption implies that stability is the norm, sporadically thrown out of equilibrium by external forces. If, as the editors suggest, migration is "integral" (p. 3) to the human condition, where, then, are these splendidly isolated communities? Further, 'disruption' seems to place the emphasis on the factors pushing people to migrate (e.g. climate change or war), ignoring those which pull them to brighter and better futures elsewhere. The editors make clear that they do not envisage migrants as passive victims and, indeed, they argue the opposite. So why choose such a problematic term, especially when it appears to be intended only as a word and not as an explanatory concept?

Perhaps the answer lies in the first chapter, which takes the form of a "comprehensive intellectual framework for investigating both the causes and consequences 
of migration throughout human history" (p. 15). This is a collaborative literature review and it formed the starting point from which the ASU workshop progressed. Significantly, the chapter's title is not unifying theory, but the more modest 'Unifying themes in studies of ancient and contemporary migrations'. Yet if the ambition has been toned down between the title of the book and that of Chapter 1, further discussion does not clarify why disruption is such a useful term. It is not, we are told, synonymous with 'disaster' (although tsunamis are expressly included); nor it is the same as 'transformation'. It can be either environmental or social, although the examples provided on page 18 cast the former as causes and the latter as effects (cf. the views of Glowacki and Drennan et al. below).

What do the contributors have to say in response to this framework? The chapters are divided into: 'Past perspectives' and 'Modern perspectives', of five and seven papers respectively. As the chapters in the first section are arranged in chronological order, it is immediately clear that the volume excludes the vast majority of human migration history, for the first contribution is 'The Anglo-Saxon migration: an archaeological case study of disruption'. In this chapter, Catherine Hills provides a very clear account of the textual and archaeological evidence, and of the changing political contexts in which it has been interpreted. This engages directly with some of the framework's themes. Yet there are also gentle cautions that seem to resist the editors' aims. The term 'disruption', Hills notes, is not really used in this area of study, and her conclusion is that we need to allow for the diversity of the evidence across time and space, and to recognise that there were lots of Anglo-Saxon migrations that played out differently. Similarly, in her chapter on 'Religious disruption and the Islamic conquest of Andalucia', Zakrewski struggles to squeeze into the collaborative framework her interesting palaeopathological work on possible skeletal markers caused by daily prayers. Cowgill uses the term 'disruption' in his subheadings, although he does not otherwise use the term in his discussion of migrants at Teotihuacan, and Knudson and TorresRouff make only minimal use of the term in their study of the Middle Horizon and Late Intermediate periods in the Andes. Beekman comes closest to fitting his material on Epiclassic Mesoamerica into the disruption model, and makes the only overt pitch in the 'Past perspectives' section in support of it.
In the 'Modern perspectives' section, De León et al. provide a thought-provoking study of how the 'tidying' of Latino material culture, left in the Sonoran Desert, by conservationists erases evidence for the presence of migrants. Here, disruption is more directly discussed but still only briefly, and it does not add obvious value. The chapter by coeditor Tsuda on perceptions of Mexican and Asian immigrants to the USA, by contrast, addresses the issue at length and with value. Perhaps, therefore, disruption is a term better suited to studies of modern migration where the experiences of migrants and host societies can be more directly documented. If so, not all the contributors agree, as suggested by the title of Morrissey's 'Rethinking "causation" and "disruption": the environment-migration nexus in northern Ethiopia'. It is no surprise that all of the 'Past perspectives' papers make reference to this chapter, for although Morrissey deals with migration in contemporary Ethiopia, he speaks in terms that archaeologists will recognise. With clarity, he spells out some of the problems with the collaborative framework, its terminology and assumptions. Indeed, he distances himself from the notion of disruption altogether and prefers the term mobility to migration. But most importantly, he demonstrates the complexity of causation-the myriad, intersecting factors that must be taken into account alongside environmental change.

There are lots of other fascinating case studies and, unlike some edited collections, care has been taken to ensure that the chapters speak directly to each other's ideas. But this does not amount to a comprehensive account of migration in human history, nor to a unifying theory. Not least, there are too many gaps in coverage-chronological, geographic and theoretical-to argue that the subject has been fully explored.

The editors' conclusions restate the concepts outlined in Chapter 1, elaborated with additional case studies. If that chapter was the "conceptual and analytical framework [...] used to generate interest among international scholars who wished to develop the premises" (pp. 6-7), it is unclear how the contributors' case studies have fed back. Hence, when the editors boldly assert that "Because of the considerable amount of intellectual discussion and exchange involved in this project, our volume has conceptual unity and coherence" (p. 12), this is less than convincing. The chapters certainly play off each other and are usefully cross-referenced. But a number 
of them, especially the 'Past perspectives', seem to work around, rather than with, the intellectual framework. The concluding chapter demonstrates the problem with this approach. For every example provided, there is another that demonstrates the opposite. Thus, on page 302 we are told that the poorest are often the ones who must migrate as they have the least resources and weakest support networks. Two pages later, however, we find that it is often the better-off who migrate because they have more resources and better support networks. And the higher the level of generalisation, the less insightful the observations become: "larger migrant groups tend to place a greater strain on limited resources and are less likely to be integrated smoothly" (p. 307), and "immigrants who differ more, both biologically and culturally, from the majority host population have greater disruptive consequences" (p. 308). The volume ends with a discussion of the framework's shortcomings, many of which archaeological readers will have already discerned through the insights of the individual case studies. In the end, these may be simply semantic problems. Or, perhaps, we really do require distinctive tools for the study of ancient and modern migration, even if we share the same ambitions.

\section{Climate refugees}

JIM LEARY. The remembered land: surviving sea-level rise after the last Ice Age. 164 pages, 10 b\&w illustrations. 2015. London \& New York: Bloomsbury; 978-147424-591-3 paperback £14.99.

Lynn H. Gamble (ed.). First coastal Californians. $\mathrm{x}+132$ pages, numerous colour and $\mathrm{b} \& \mathrm{w}$ illustrations. 2015. Albuquerque: University of New Mexico Press; 978-1-938645-19-8 paperback £24.95.

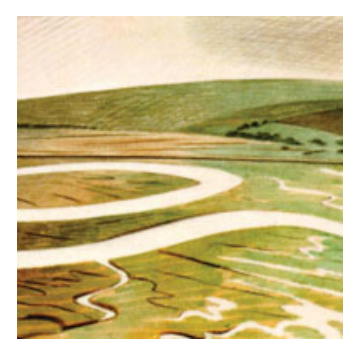

A book very different in style and format, although still fundamentally concerned with migration, is The remembered land: surviving sea-level rise after the last Ice Age by JiM LEARY. Even though awareness of a lost land under the North Sea goes back over a century, our knowledge about it has increased exponentially in the last couple of decades. Indeed, that work has rendered obsolete the widely recognised name for this territory: Doggerland. As Leary explains (oddly tucked away in an endnote), we now know that the Dogger Bank was formed as a result of tidal action following inundation, meaning that it was not a distinctive landscape feature for prehistoric people. Instead, therefore, he reverts to an older name: Northsealand.

Leary draws widely on ethnographic parallels from the Arctic to Australia, and engages with diverse specialisms including folklore, ecology, geology and geophysics. He eschews a chronological structure, documenting the advancing and retreating coastlines in favour of cross-cutting themes that put the human experience first and foremost. Leary explains: "The approach taken in this book is an alternative to traditional conceptions of 'victims' of sea-level change; of legions of noble, head-bowed, Mesolithic men, women and children, trudging away from their flooded homes" (p. 110). Migration therefore forms only one of several themes and, in doing so, illustrates the need to approach it as a more complex phenomenon than disruption and departure. Leary stresses the importance of understanding the social and emotional responses to environmental change and of recognising that people are part of the (ever-changing) environment, and that therefore there is no 'external' disruption. Put plainly, "People were not just 'coping', but getting on with life" (p. 106).

Leary stresses two main issues. Firstly, change was fitful: temperature fluctuations, sea levels rising and falling, islands appearing and disappearing, unpredictable tides and tsunamis. Plants, animals and resources such as flint may have been lost, but new opportunities may also have arisen. Secondly, responses were conditioned by social organisation, emotions and taboos. Of vital importance were social networks - a phrase and concept used in all the books under review here-which allowed groups to adapt cooperatively and continually to the world around them. Leary even suggests that submergence may not have been perceived as the loss of land, but rather as the widening of the sea, offering better access to maritime resources, even encouraging people to take to the water. Nonetheless, the "coastal squeeze" (p. 57) may have led to suspicion of immigrants, tensions and even warfare.

This book is published in the Bloomsbury 'Debates in Archaeology' series, although the subject matter is not explicitly presented as a matter of debate. 
What will be more discussed, perhaps, is the style of presentation. The text is characterised by expressions such as "it may be that" and "it is interesting to speculate". Inevitably, this is in part due to the nature of the evidence, but also partly a result of Leary's ambition to get to the human experience neglected by many traditional accounts. He further adopts a Romantic tone with drawings of Mesolithic people and landscapes, the use of epigraphs (including the shipping forecast) and a fictionalised vignette for an epilogue. In style, therefore, this book shares similarities with Mark Edmonds's (1999) Ancestral geographies of the Neolithic.

A real omission is a decent map. The one provided, echoing the Romantic character of the text, resembles a Swallows and Amazons treasure map - evocative, but lacking what many readers may want, including an indication of how the coastlines of today relate to those of the past (indeed, what date does Leary's map represent?) and the locations of the excavated sites discussed. This latter omission is particularly acute when Leary takes the reader on an "imaginary walk" (p. 15) around Northsealand.

As a counterpoint to recent work that has used hitech approaches to study complex geomorphological processes across huge territories, Leary encourages us to think about the human scale and to consider how this can profoundly shape responses, including migration, to environmental change. The submergence of Northsealand is not simply a tale of disruption and loss caused by geological and ecological processes, but rather a human drama played out in an inhabited landscape. Leary does not belabour the relevance of prehistoric sea-level change for the modern world, but his concluding juxtaposition, of North Sea fishermen hauling up stone tools in their nets with a Pacific Islander up to his ankles in water, poetically and powerfully makes the point.

Half a world away, the post-Ice Age tide was also rising along the California seaboard, with dramatic effects on the coastline. First coastal Californians, edited by LYNN GAMBLE, provides an accessible introduction to recent archaeological work in southern California, and migration is one of the key themes. Published by the Santa Fe School for Advanced Research, the volume features 17 short contributions by key scholars. Brian Fagan provides a Foreword and his well-known writing style is imitated in many of the papers, which begin with evocative paragraphs imagining past events or recounting the experiences of archaeologists in the field. The volume is a miscellany rather than a comprehensive survey. Collectively, however, the contributions provide broad chronological coverage of the major changes in environment and human activity. The theme of migration runs throughout, from the first peopling of the region to the colonial and modern eras.

Questions about the conventional explanation of the arrival of humans in North America are raised by Erlandson and Rick in their discussion of the 'kelp highway' theory. California and the Pacific coast are usually considered to have been colonised in a secondary phase, following primary colonisation across Beringia and down to the Great Plains. Interest is growing, however, in a direct migration route down the Pacific coast that would have exploited the rich coastal waters (first touted at least 40 years ago, see Fladmark 1979). Yet, as the authors note, testing this hypothesis is difficult, as any evidence would be submerged more than $100 \mathrm{~m}$ below current sea levels. New clues from California's Channel Islands are therefore tantalising. The re-dating of skeletal collections suggests human activity contemporary with the Clovis culture to the east; the material culture associated with the Channel Island skeletons, however, is clearly not Clovis. Much more evidence will be required, but, if proven, the 'kelp highway' hypothesis would have significant implications for the narrative of one of the major human migrations.

Beyond the question of when and how humans first arrived, other chapters explore migration in a range of contexts from sea level rise, habitat loss and drought, through colonial occupation, to the immigration of miners and settlers in the 1850 s and 1860s. For example, Masters and Porcasi observe how tidal estuaries gave way to coastal valleys and, eventually, by around 5000 years ago, to long sandy beaches—great for tourism, but a significant reduction in biodiversity for hunter-fisher-gatherers. Similarly, Douglass et al. present a reconstruction of the transformation of Ballona Creek from a tidal river into a lagoon over eight millennia, with associated shifts in exploitation strategies and settlement.

The chapter by Kent Lightfoot and colleagues examines the evidence for shell mounds on San Francisco Bay (see also book reviews by Pluckhahn and Rosenswig in this issue). The authors build on pioneering work undertaken over a century ago that documented more than 400 shell mounds, almost all of which have been subsequently destroyed. A new programme to date museum specimens demonstrates

(C) Antiquity Publications Ltd, 2016 
that some mounds continued in use well into the eighteenth century, that is, 300 years after the arrival of the Spanish. In relation to ongoing debate about the function of shell mounds, work on the Ellis Landing mound suggests feasting, ceremonies and burial were the primary activities for several millennia before shifting, c. AD 900, to domestic occupation in the form of a village.

The coastal Californians seem to have repeatedly found ways to adapt to environmental stress, such as drought, as demonstrated by Terry Jones's review of long-term changes in socio-economic organisation and technology. The situation was, however, different on the Channel Islands. Here, Jennifer Perry and colleagues describe how the concentration of the population into villages caused greater stress when drought struck as there was nowhere else on the islands to move to. Nonetheless, the islands remained populated into the 1820s when the last inhabitants were relocated to mainland missions. Erlandson and Vellanoweth report on an archaeological discovery that may relate to the last person to leave the island of San Nicolas: a woman called Juana Maria, who left in 1853. Coastal erosion in 2009 revealed a wooden box containing abalone-shell dishes, stone knives, projectile points and other finds that indicate a midnineteenth-century date. Although this treasure trove cannot be directly linked to the island's final emigrant, its date makes this a possibility.

Other chapters discuss the transformation of the landscape through the intentional use of fire (rather different from the Californian experience of fire today), seafaring, Chumash rock paintings and the 'cultural earthquake' of Spanish colonisation and the responses to it. First coastal Californians is beautifully illustrated with colour reconstruction drawings, archival photographs and maps. California may seem distant from Northsealand, but the colour photograph (pl. 12) of the Point Reyes National Seashore is remarkably similar to the cover image of The remembered land, and it is perhaps no coincidence that Leary alludes to the experience of Chumash hunter-fisher-gatherers in his discussion of the European Mesolithic.

This volume communicates the pace of research in southern California and sets discoveries in a wider context. It does this in an accessible way and also sensitively relates work on the past with the revival of Native American groups in the present. It is not explicitly about migration, but the theme runs strongly through the region's history, from the first peopling, perhaps more than 12000 years ago, to the Gold Rush and the Homestead Act of the nineteenth century. Our next book, by contrast, narrows down the chronological focus to concentrate on what looks like—at least superficially—a single migration event.

\section{The long goodbye}

Donna M. GLOWACKI. Living and leaving: a social history of regional depopulation in thirteenthcentury Mesa Verde. 2015. xiii+396 pages, 38 b\&w illustrations, 13 tables. Tucson: University of Arizona Press; 978-0-8165-3133-2 hardback \$60.

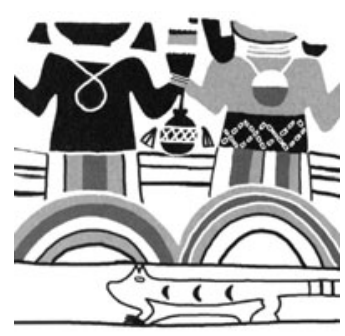

If the early populations of Northsealand left because of too much water, the Pueblo people of Mesa Verde in the US Southwest were confronted by too little. How they responded is examined by DONNA GLOWACKI in Living and leaving: a social history of regional depopulation in thirteenth-century Mesa Verde. During the later thirteenth century AD, this region witnessed not just emigration but a mass exodus.

Glowacki asks why some societies can find ways of reorganising to solve problems, whereas others turn to migration - or 'leaving'. As with Leary, her interests lie as much with the alternatives to migration that are considered before the final decision to migrate. And again echoing Leary, the emphasis falls on the social and religious as much as the climatic, economic or environmental. Usefully, the standard push-pull migration model is reworked as stressors and enablers. The latter, in particular, extends the idea of pull factors to deal both with what attracts migrants into an area and consideration of the potential migrant's ability to perceive and respond to these factors as a result of knowledge and resources-social networks again.

Six core chapters analyse the changing environmental, economic, social and political landscapes across the twelfth and thirteenth centuries. Chapter 2, 'Laying the groundwork', introduces the geography. Despite the use of Mesa Verde in the book's title, Glowacki's study area encompasses a broader $20000 \mathrm{~km}^{2}$ region along the northern bank of the San Juan River. Crucial to the subsequent analysis is the division of this

(C) Antiquity Publications Ltd, 2016 
elongated territory into a series of subregions. The next chapter, 'Mapping spatial experience', introduces a database of nearly 4000 Pueblo III (AD 1150-1300) habitation sites, of which she concentrates on 253 'community centres', or large, aggregated villages.

Glowacki's analysis suggests that, regionally, the population grew steadily during the second half of the twelfth century and increased rapidly between AD 1200 and 1220. It then declined sharply from the mid thirteenth century, with almost complete depopulation within a few decades. The subregions, however, differ markedly in terms of settlement organisation, population trends and, as demonstrated in Chapter 4, the production and exchange of pottery. Glowacki argues that these variations were deep rooted and are fundamental to understanding the different ways in which groups responded to the environmental and social stresses of the twelfth and thirteenth centuries-even if they all eventually reached the same final decision to leave. Migrations are "historically situated, contingent occurrences created and influenced by the conditions and actions that came before" (p. 133). To this end, Chapter 5, 'Interpreting the historical landscapes', explores the differences between the eastern and western areas (e.g. the former was twice as densely populated and had four times the number of community centres) and the differing subregional responses to the political and ideological influence of Chaco, and then Aztec, over $100 \mathrm{~km}$ to the south. For example, in the McElmo subregion, there is evidence for violence in the form of skeletal trauma; at the Cowboy Wash community, occupation ended violently with individuals "butchered, roasted, and consumed" (p. 158). Even more disturbing in the context of our migration theme is that the victims may have been an immigrant Chaco community.

The thirteenth century began with population growth and aggregation, along with new levels of ceremonialism. But this led to new tensions, and as community interdistance decreased, the risk of conflict increased. Combined with worsening farming conditions, religious dispute and an absence of central authority, the situation "reached critical mass in the mid-1200s" (p. 193). The final chapter, 'Leaving Mesa Verde', considers the resulting regional depopulation. The long build-up to this migration through the previous chapters underlines that this was neither a sudden decision nor simple cause and effect. Rather, it was the result of "cascading ramifications" (p. 217) that can be traced back for decades, even centuries: "The mid-1200s were clearly a tipping point $[\ldots]$ one that apparently involved too much change, too fast, during an uncertain time. The conditions under which people emigrated were extreme, especially socially" (p. 198). The timing and pace of emigration varied between the subregions, beginning in the $\mathrm{AD} 1240$ s and accelerating after $\mathrm{AD}$ 1260. In the western areas, the more dispersed and mobile population found it easier to dissociate from the social and political problems of the wider regionand hence easier to leave. The situation in the eastern areas was different. Here, the combination of larger and more nucleated populations, social and religious upheaval and severe drought in the late AD 1270s and 1280 s eventually led to the same outcome, but at a later date, more rapidly and possibly more violently. In total, perhaps 10000 people left within a generation - a paltry figure compared to the millions on the move today, but dramatic for the fact that this was an entire population. By AD 1285, the region was almost completely depopulated; questions about where they went and why they did not return are less easily answered. In the 'Lessons learned' section, Glowacki stresses the need for the long-term view of migration, the diversity of stressors and enablers, and recognition that communities might arrive at the same decision for different reasons. Population size and environmental stress are only part of the story; it was also the convergence of social, political and religious challenges that brought these communities to "a tipping point" requiring a "reset" (p. 216).

Living and leaving is a well-argued and coherent account, supported with primary data and illustrated with striking black-and-white photographs that give a sense of the landscape. The maps are consistently reproduced, aiding navigation, but are rather small and could have been rotated to make better use of the page extent. The scale of the depopulation documented at Mesa Verde, and the fact that the migrants did not return, makes this example historically unusual. Nonetheless, Glowacki's book provides a valuable case study for those working on migration elsewhere, most especially for its emphasis on the long-term perspective of leaving.

\section{The number games}

Robert D. Drennan, C. Adam Berrey \& Christian E. Peterson. Regional settlement demography in archaeology. 2015. ix+180 pages,

(C) Antiquity Publications Ltd, 2016 
numerous b\&w illustrations, and tables. Clinton Corners (NY): Eliot Werner; 978-0-9898249-1 paperback $\$ 32.95$.

Justine M. SHaw (ed.). The Maya of the Cochuah region: archaeological and ethnographic perspectives on the northern lowlands. 2015. $\mathrm{xv}+328$ pages, numerous illustrations, 7 tables. Albuquerque: University of New Mexico Press; 978-0-8263-4864-7 hardback $\$ 85$.

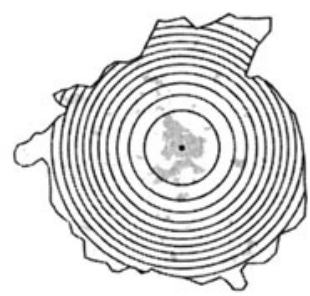

Of the books
considered so
far, Glowacki's is
the only one to
attempt-however
briefly- to quantify
the number of
people on the move.
The next volume,
Regional settlement demography in archaeology by DRENNAN, BERREY and Peterson, tackles the subject head-on. The title of Chapter 1, 'Regional settlement demography: why bother?', gives a flavour of the approach. The book is the second in Eliot Werner's 'Principles of Archaeology' series of short primers authored by high-profile scholars. The brisk text, intended as an introduction and guide to best practice, replaces in-text citation with annotated suggested reading at the end of each short chapter, along with question-and-answer sections.

The authors start from the premise that all regional settlement survey is fundamentally about demography. They argue that there are believers and sceptics, but that the latter still harbour powerful demographic assumptions: "Tell a Mesoamericanist excavating an initial Formative village that you think that it had 5,000 residents, or remark to the excavator of a Longshan walled town with the remains of a palace that you think its population was less than 1,000 , and you'll quickly be challenged" ( $p$. 5). Drennan et al. then set about making explicit such assumptions and exploring how archaeologists have quantified population. They review proxies such as radiocarbon dates, numbers of sites, houses or rooms, site size, residential density and the quantity of surface artefacts. A key recommendation is that, where possible, archaeologists should calculate an area-density index combining site size with artefact density. They also review methods for visualising and analysing settlement distribution and trends; for example, creating density surface maps and comparing the pros and cons of rank-size graphs with a technique, pioneered by the authors, using concentric circles.

The authors expose and address almost every imaginable assumption and the discussion of each is inevitably brief, but the treatment of consumption feels particularly underplayed. The authors place much weight on the idea that more people produce more 'garbage'. While this might be a useful rule of thumb, however, factors as diverse as market integration and taphonomy confound any simple equation between pots and people. Certainly, solutions are proposed - such as using ceramic fabric rather than form-but the issue is perhaps more significant than suggested.

Several times, the authors compare demographic archaeologists with modern census-takers. A problem for both is that people move around, making them difficult to count. This brings us back to migration. How can we count people if they were commuting between town and country, mountains and coast, and one region and another? A short section tackles seasonality, temporary residence and contemporaneity. The headline message is positive: "Human groups move around the landscape and the only thing that differentiates these problems of contemporaneity, seasonality, and high mobility is the temporal scale on which movement occurs" (p. 118). The solution is to find methods or proxies to eliminate these confounding factors, and the authors provide examples of the way forward, mostly drawn from their own work. As a manual of best practice, we would expect such a 'can-do' attitude. In places, however, it may have been instructiveeven reassuring - to have included some 'sub-optimal' case studies to help the aspiring demographer think through the application of these techniques in the less-than-ideal circumstances more typically encountered.

Most of the book focuses on relative population numbers, but Chapter 4 turns to absolute figures: the "most error-prone part of regional settlement demography" (p. 99). The authors suggest that they consider published figures such as 72.2 persons/ha to be "hyper-precise" (p. 106) - they would interpret this to mean $50-100$ persons/ha. This observation gives a sense of the margins of error deemed acceptable and is a reminder that Drennan et al. are not attempting to count every individual. Some, however, will be uncomfortable with the search for the 'magic number', that is, "the number of people whose garbage 
accumulated over one century [that] will on average leave an archaeological sherd scatter of $1 \mathrm{sherd} / \mathrm{m}^{2}$ across an area of 1 ha" (p. 111).

The authors convincingly redefine survey as "irreducibly" (p. 91) demographic and lay out a rigorous methodology. An unintended effect, however, is that surveys that have collected data less systematically are side-lined. This may explain the almost complete absence of the Near East and, especially, the Mediterranean, the latter meriting just two or three passing mentions with the observation that work in this region operates on a scale below that required for regional demographic modelling. Adopting this position, the authors reflect, but do not cite, the views of fellow Mesoamericanist Richard Blanton in his Antiquity paper, 'Mediterranean myopia' (2001), which chastised surveyors in that region for the ever smaller size of their survey areas. There are good reasons for the differences in the scale of surveys in the Mediterranean and Mesoamerica (and there are certainly Mediterranean surveys that exceed the authors" threshold of " $100 \mathrm{~km}^{2}$ or more", p. 6). In reality, the absence of Mediterranean examples seems to result from their lack of methodological sophistication of the sort demanded here. It would certainly be difficult to apply these methods to any but the most recent Mediterranean surveys (although in a Catch-22, these are precisely the smallest, and hence disqualified).

This leaves Mediterranean survey in a bind. There are big questions about demography, and surveyors have collected masses of data, have excellent ceramic typologies and good independent checks. But the methods defined here leave the Mediterranean all at sea. Certainly, existing attempts at demographic reconstruction in the Mediterranean are unsophisticated compared to those pioneered by Drennan et al.-perhaps all the more reason that it would have been valuable to have their thoughts. Should Mediterranean surveyors abandon seven decades of work and implement a new series of surveys using the method espoused here? On that issue, the penultimate chapter poses the question: "How can we collect regional settlement data for demographic analysis?" This will be useful reading for regional surveyors generally, and for Mediterranean archaeologists in particular.

Regional settlement demography is full of wisdom based on long experience and should make archaeologists of any period or region think hard about the scale, distribution and organisation of the populations who produced the architecture and artefacts documented by survey. As evangelists for demographic archaeology, the authors' message is unsurprisingly positive-no problem is insurmountable with the right method or data. Some readers may be left frustrated that their own data do not make the grade. If so, Drennan et al. have not simply thrown down the gauntlet to aspire to better theory, method and interpretation, but have also provided a guide for how to achieve this end. It will be challenging, but the authors make a compelling case for why it is worth the 'bother'.

Finally, we conclude with an example of precisely the sort of project that does not feature in Drennan et al.'s primer, but which is, nonetheless, concerned with demography and the effects of migration on population size and trends. The Maya of the Cochuah region: archaeological and ethnographic perspectives on the northern lowlands, edited by JUSTINE SHAW, presents results from the first dozen years of the Cochuah Regional Archaeological Survey in northern Yucatán, Mexico. The project focuses on activity from the Middle Formative period through to the present and has identified dozens of archaeological sites. The main prospection technique has used local informants to guide surveyors to sites (not a technique featured in Drennan et al.), combined with a testpitting programme. The project's aims focus on reconstructing regional settlement and population dynamics.

Shaw's introductory chapter provides an overview of developments across the wider Maya world and summarises the parallel situation in the Cochuah region. The narrative begins, appropriately for our theme, with the movement of coastal populations into inland areas during the Middle Formative, and the summaries of each subsequent period are characterised by change in population size and distribution. A period of sharp contrast with developments in the southern Maya lowlands is the Terminal Classic; the 'collapse' experienced to the south contrasts with a marked peak in activity in Cochuah. Shaw continues the narrative through the Spanish Colonial period, with its reducción policy, and into the complex developments of the nineteenth and twentieth centuries, such as the Caste War, and their effects on the population.

The chapters cover a wide range of topics, presented in broadly chronological order. They include studies of ceramic exchange, carvings and miniature shrines; others focus on individual sites, such as Colonialperiod Ichmul. Bringing the past up to the present,

(C) Antiquity Publications Ltd, 2016 
there is an anthropological discussion of how local women experience health care today, and the contrasting perceptions of 'traditional' Maya knowledge. Frustratingly, the illustrations do not give much sense of the landscape. Admittedly, this is not the most topographically varied terrain to map or to photograph, but the reader will not get a feel for Cochuah-the vegetation, the distribution of water sources or the ways of moving around.

From a migration perspective, an important chapter is Shaw's consideration of 'The problem of mobility in estimating the extent of Terminal Classic, populations in Cochuah'. Shaw observes a dramatic spike in the quantity of pottery during the Terminal Classic, and she takes this to indicate a population peak, in marked contrast to the much-discussed 'collapse' in the southern lowlands (the causes of which she notes are complex and not to be explained monocausally by drought). Shaw cautions, however, that the twentyfold increase in pottery at Cochuah cannot be taken as a direct proxy for the scale of population increase. Terminal Classic pottery is more durable, and therefore better preserved, than the pottery from earlier periods-a possibility recognised by Drennan et al. Shaw also observes that the settlement and population seem to have dispersed in order to make better use of water sources during this dry period, with new levels of mobility, for example, between central settlements and field shelters. Combined, these considerations have dramatically exaggerated the visibility of the Terminal Classic (again, consumption could have been given further consideration-do people consume more pottery because they are more mobile?). Shaw, nonetheless, is confidentand convincing-in suggesting that the underlying population increase was still such that it probably combined both natural growth and immigration from the southern lowlands, even though there is no evidence such as changing material culture to support the latter. Here, then, are many of the problems diagnosed by Drennan et al.- the messy reality in need of mitigating methods-but also an example of some of the barriers encountered by surveys to implementing suggested solutionsfor example, isotope analysis of human bone raises sensitive issues in this context, and middens have been recycled and are not therefore a useful proxy.

On the subject of mobility, Flores Colin discusses sacbeob, or artificial causeways. He provides a detailed description of the sacbeob mapped in the study region and reinterprets their function and significance. $\mathrm{He}$ argues that a situation has arisen whereby any and all theories about the use of these causeways are considered to be equally possible ("multiexplicative", p. 156), reducing the potential for nuanced interpretation. In contrast, he proposes that the different arrangements of space and architecture at the destination of each causeway indicate differences in use. Some were for large-scale processions and ceremonies, and others were for smallerscale kin-based rituals. He also suggests that the mortuary phrase 'och b'ih-'entering in the road'was more than a metaphor for death, and that these causeways may have served as funerary procession routes-the ultimate migration, from life to death.

The Maya of the Cochuah region is an interim statement rather than a master narrative. When the latter is written, however, it is clear that migration and mobility will be central to the story, from the earliest occupation of the region through to the present. All of which brings us to the end of our own journey. Today, migration is a topic of the highest societal concern. In their different ways, each of these books reflects on this theme-either as its central concern or as an integral part of the interpretation. The picture that emerges is one of historical contingency and great variation across time and space. Such diversity might be all the more reason for developing a common language or even concepts (if not a unified theory) with which to discuss human mobility. As the case studies reviewed here demonstrate, migration can involve loss and coercion, resulting from colonisation, slavery, war or environmental stress. But people also actively choose to move as well, and hence both the push and the pull-the stressors and the enablersneed to be considered. There is also a lot of mitigation before migration; we need to look at the long-term causes, not just the 'proximal triggers' of migration. Finally, at a time when Europe is experiencing a 'migrant crisis' and a key issue in the US presidential race is the construction of a wall along the Mexican border, it is interesting to observe that the long-term view suggests migration is a decidedly 'normal' state of affairs.

\section{References}

Blanton, R.E. 2001. Mediterranean myopia. Antiquity 75: 627-29.

http://doi:10.1017/S0003598X00088918.

(C) Antiquity Publications Ltd, 2016 
EDMONDS, M. 1999. Ancestral geographies of the Neolithic. London: Routledge.

FLADMARK, K.R. 1979. Routes: alternate migration corridors for Early Man in North America. American Antiquity 44: 55-69. http://doi:10.2307/279189.

\section{Books received}

This list includes all books received between 1 January 2016 and 29 February 2016. Those featuring at the beginning of New Book Chronicle have, however, not been duplicated in this list. The listing of a book in this chronicle does not preclude its subsequent review in Antiquity.

\section{General}

Emily Miller Bonney, Kathryn J. Franklin \& JAMES A. JOHNSON (ed.). Incomplete archaeologies. 2015. xix +148 pages, several b\&w illustrations. Oxford \& Havertown (PA): Oxbow; 978-1-78570-115-3paperback $£ 36$.

GEOFF EMBERLING (ed.). Social theory in archaeology and ancient history: the present and future of counternarratives. 2016. xvi+366 pages, several b\&w illustrations. New York: Cambridge University Press; 978-1-107-05333-5 hardback £74.99.

BRIAN HOBLEY. The circle of God. An archaeological and historical search for the nature of the sacred: a study of continuity. 2015. v+807 pages, numerous colour and b\&w illustrations. Oxford: Archaeopress; 978-1-78491-137-9paperback $£ 110$.

MATTHEW E. KeITH (ed.). Site formation processes of submerged shipwrecks. 2016. ix +276 pages, numerous b\&w illustrations, 10 tables. Gainesville: University Press of Florida; 978-0-8130-6162-7 hardback $£ 73.95$.

STEPHEN LEACH. A Russian perspective on theoretical archaeology: the life and work of Leo S. Klejn. 2015. 221 pages, several b\&w illustrations. Walnut Creek (CA): Left Coast; 978-1-62958-138-5 hardback $\$ 79$.

Colin Renfrew, Michael J. Boyd \& IAin Morley (ed.). Death rituals, social order and the archaeology of immortality in the ancient world. 2016. xxiii+443 pages, numerous b\&w illustrations. New York: Cambridge University Press; 978-1-107-08273-1 hardback $£ 75$.

Maria Theresia Starzmann \& John R. Roby (ed.). Excavating memory: sites of remembering and forgetting. 2016. $x v+405$ pages, several b\&w illustrations. Gainesville: University Press of Florida; 978-0-8130-6160-3 hardback \$100.

(C) Antiquity Publications Ltd, 2016

\section{European pre- and protohistory}

PAUl G. BAHN. Images of the Ice Age. 2016 (third edition, first published in 1988). xxiv+480 pages, 350 colour illustrations. Oxford: Oxford University Press; 978-0-19968600-1 hardback $£ 30$.

Richard Bradley, Colin Haselgrove, MarC VANDER Linden \& LEO Webley. The later prehistory of north-west Europe: the evidence of development-led fieldwork. 2016. xviii+456 pages, 120 b\&w illustrations. Oxford: Oxford University Press; 978-0-19-965977-7 hardback $£ 90$.

Primitiva Bueno-Ramírez \& Paul G. Bahn (ed.). Prehistoric art as prehistoric culture. Studies in honour of Professor Rodrigo de Balbin-Behrmann. 2015. $\mathrm{x}+180$ pages, numerous colour and $\mathrm{b} \& \mathrm{w}$ illustrations. Oxford: Archaeopress; 978-1-78491-222-2 paperback $£ 45$.

Roland GAUss. Zambujal und die Anfänge der Metallurgie in der Estremadura (Portugal). Technologie der Kupfergewinnung, Herkunft des Metalls und soziokulturelle Bedeutung der Innovation (Iberia Archaeologica 15, Faszikel 1). 2015. 332 pages, 111 colour and b\&w illustrations, 39 tables. Tübingen: Ernst Wasmuth; 978-3-8030-0241-9 hardback $€ 99$.

LUC LAPORTE \& CHRISTOPHER SCARRE (ed.). The megalithic architectures of Europe. 2016. xi+240 pages, numerous colour and b\&w illustrations. Oxford \& Havertown (PA): Oxbow; 978-1-78570-014-9 hardback $£ 55$.

Johannes MÜller, Knut Rassmann \& MiKHAIL VIDEIKO (ed.). Trypillia: mega-sites and European prehistory 4100-3400 BCE (Themes in Contemporary Archaeology 2). 2016. xviii +311 pages, numerous colour and b\&w illustrations, tables. Abingdon: Maney; 978-1-910-52602-6 hardback $£ 55$.

Courtney Nimura. Prehistoric rock art in Scandinavia. 2015. xii+141 pages, numerous colour and b\&w illustrations. Oxford \& Havertown (PA): Oxbow; 978-1-78570-119-1 paperback $£ 25$.

Heidrun StebergløKKen, Ragnhild Berge, EVA LindgaARD \& Helle VANGEN STUEdal (ed.). Ritual landscapes and borders within rock art research. Papers in honour of Professor Kalle Sognnes. 2015. viii 188 pages, numerous colour and $b \& w$ illustrations. Oxford: Archaeopress; 978-1-78491-158-1 paperback $£ 35$.

\section{Mediterranean archaeology}

DaVid ABUlafia (ed.). The Mediterranean in history. 2016 (first published in hardback 2003). 320 pages, 308 colour and b\&w illustrations. London: Thames \& Hudson; 978-0-500-29217-4 paperback $£ 16.95$. 
Tiziana Matarazzo. Micromorphological analysis of activity areas sealed by Vesuvius' Avellino eruption. The Early Bronze Age village of Afragola in southern Italy. 2015. viii +200 pages, numerous colour and b\&w illustrations, tables. Oxford: Archaeopress; 978-1-78491-211-6 paperback £38.

IAN McPheE (ed.). Myth, drama and style in south Italian vase-painting. 2016. $\mathrm{xl}+299$ pages, numerous b\&w illustrations. Uppsala: Astrom; 978-91-7081-205-7 hardback €63.60.

\section{The Classical and Roman worlds}

Honora Howell Chapman \& Zuleika Rodgers (ed.). A companion to Josephus. xi+466 pages, several b\&w illustrations. 2016. Chichester: Wiley-Blackwell; 978-1-4443-3533-0 hardback $£ 120$.

Gilbert J. Gorski \& James E. Packer. The Roman Forum: a reconstruction and architectural guide. 2015. xxii+437 pages, 247 colour and 60 b\&w illustrations. New York: Cambridge University Press; 978-0-521-19244-6 hardback $£ 150$.

RUBinA RAJA \& JORG RÜPKE (ed.). A companion to the archaeology of religion in the ancient world. 2015. xiii +502 pages, several b\&w illustrations. Chichester: Wiley-Blackwell; 978-1-4443-5000-5 hardback $£ 120$.

R.R.R. SMITH \& BRYAN WARD-PERKINS (ed.). The last statues of antiquity. 2016. viii+410 pages, $184 \mathrm{~b} \& \mathrm{w}$ illustrations. New York: Oxford University Press; 978-0-19-875332-2 hardback £100.

CONOR TRAINOR. The ceramics industry of Roman Sikyon: a technological study. 2015. xviii+125 pages, numerous colour and b\&w illustrations. Uppsala: Astrom; 978-91-7081-203-3 hardback €36.

Hilary \& John Travis. Roman shields. 2015. 192 pages, numerous colour and b\&w illustrations. Stroud: Amberley; 978-1-4456-5523-9 paperback $£ 25$.

\section{Anatolia, Levant and the Middle East}

Christoph BaChHuber. Citadel and cemetery in Early Bronze Age Anatolia (Monographs in Mediterranean Archaeology 13). 2015. xv+222 pages, 5 colour and 42 b\&w illustrations. Sheffield \& Bristol (CT): Equinox; 978-1-84553-648-0 hardback $£ 70$.

Sylvie BlÉTRY. Zénobia-Halabiya, habitat urbain et nécropoles. Cinq années de recherches de la mission syro-française (2006-2010). 2015. 574 pages, numerous b\&w illustrations, tables. Montpellier: Presses universitaires de la Méditerranée; 978-84-608-1605-8 hardback $€ 68$.

IAN HODDER \& ARKADIUSZ MARCINIAK (ed.). Assembling Chatalhöyük (Themes in Contemporary
Archaeology 1). 2015. xi+201 pages, numerous colour and b\&w illustrations, tables. Abingdon: Maney; 978-1910526002 hardback $£ 50$.

SusAN Niditch (ed.). The Wiley Blackwell companion to ancient Israel. xiii +547 pages. 2016. Chichester: Wiley-Blackwell; 978-0-470-65677-8 hardback $£ 120$.

Urs Peschlow. Ankara. Die bauarchaologischen Hinterlassenschaften aus romischer und byzantinischer Zeit. 2015. 2 volumes, 486 pages, numerous colour and b\&w illustrations. Wien: Phoibus; 978-3-85161-132-8 hardback $€ 129$.

\section{Asia}

Marie-Francoise Boussac, Jean Francoise-Salles \& JeAn-Baptiste Yon (ed.). Ports of the ancient Indian Ocean. 2016. xi+559 pages, numerous b\&w illustrations. Delhi: Primus; 978-93-84082-07-9 hardback INR 2195.

ANNA KäLLÉN. Stones standing: archaeology, colonialism, and ecotourism in northern Laos (Critical Cultural Heritage Series 11). 2015. 244 pages, numerous b\&w illustrations. Walnut Creek (CA): Left Coast; 978-1-62958-098-2 hardback £64.50.

Nam C. KIm. The origins of ancient Vietnam. 2015. xii+335 pages, 39 b\&w illustrations. New York: Oxford University Press; 978-0-19-998088-8 hardback. $£ 41.99$.

SheEna Panja, Arun K. Nag \& SUNANDO BANDOPADHYAY. Living with floods: archaeology of a settlement in the Lower Ganga Plains, c. 600-1800 CE. 2015. xvi+292 pages, numerous colour and b\&w illustrations. Delhi: Primus; 978-93-84082-59-8 hardback INR 1900.

ARUNA PARITI. Genealogy, time and identity: historical consciousness in the Deccan, sixth century CE-twelfth century CE. 2015. xiii+352 pages. Delhi: Primus; 978-93-84082-47-3 hardback INR 1395.

SHEREEn Ratnagar. Harappan archaeology: early state perspectives. $2015 . \mathrm{x}+350$ pages. Delhi: Primus; 978-93-84082-60-4 hardback INR 1295.

\section{Africa and Egypt}

Graham Connah. African civilizations: an archaeological perspective. 2016 (third edition, first published 1987). xiii+412 pages, $74 \mathrm{~b} \& \mathrm{w}$ illustrations, 18 maps. New York: Cambridge University Press; 978-1-107-62127-5 paperback $\$ 42.99$.

Marianne Eaton-Krauss. The unknown Tutankhamun. 2016. xi+175 pages, 80 colour and b\&w illustrations. London: Bloomsbury; 978-1-4725-7561-6 paperback £19.99.

(C) Antiquity Publications Ltd, 2016 
FRANK FÖRSTER. Der Abu Ballas-Weg. Eine pharaonische Karawanenroute durch die Libysche Wïste (Africa Praehistorica 28). 2015. 620 pages, 376 colour and b\&w illustrations, 23 tables. Köln: Heinrich Barth Institute; 978-3-927688-42-1 hardback €78.

GENE KRITSKY. The Tears of Re: beekeeping in ancient Egypt. 2015. xiii+133 pages, numerous b\&w illustrations. New York: Oxford University Press; 978-0-19-936138-0 hardback £19.99.

\section{Americas}

Terry A. BARNHART. American antiquities: revisiting the origins of American archaeology. 2015. xviii +574 pages, $28 \mathrm{~b} \& \mathrm{w}$ illustrations. Lincoln: University of Nebraska Press; 978-0-8032-6842-5 hardback £54.

NANCY GOnLIN \& KirK D. French (ed.). Human adaptation in ancient Mesoamerica: empirical approaches to Mesoamerican archaeology. 2015. xxix+374 pages, 69 b\&w illustrations. Boulder: University Press of Colorado; 978-1-60732-391-4 hardback $\$ 60$.

William A. Haviland. Excavations in residential areas of Tikal-group 7F-1 (Tikal Report 22). 2015. iv +232 pages, 43 b\&w illustrations, tables. Philadelphia: University of Pennsylvania Press; 978-1-934536-81-0 hardback $£ 42.50$.

PATRICK VINTON KIRCH. Unearthing the Polynesian past: explorations and adventures of an island archaeologist. 2015. xix +379 pages, 70 b\&w illustrations. Honolulu: University of Hawai' $i$ Press; 978-0-8248-5345-7 hardback \$45.

JAY MILLER. Ancestral mounds: vitality and volatility of Native America. 2015. xxviii+187 pages, 3 b\&w illustrations. Lincoln: University of Nebraska Press; 978-0-8032-7866-0 hardback \$55.

C. Margaret Scarry \& Vincas P. Steponaitis (ed.). Rethinking Moundville and its hinterland. 2016. $\mathrm{xx}+321$ pages, numerous b\&w illustrations, tables. Gainesville: University Press of Florida; 978-0-8130-6166-5 hardback £64.95.

ANDREW K. SCHERER. Mortuary landscapes of the Classic Maya: rituals of body and soul. 2015. xiv+291 pages, numerous colour and b\&w illustrations. Austin: University of Texas Press; 978-1-4773-0051-0 hardback $\$ 65$.

\section{Britain and Ireland}

Anne Crone \& ERLEnd HindmarCH with AleX WoOlf. Living and dying at Auldhame: the excavation of an Anglian monastic settlement and medieval parish church. 2016. xvi+233 pages, numerous colour and b\&w illustrations, tables. Edinburgh: Society of Antiquaries of Scotland; 978-1-908332-01-1 hardback £25.

C) Antiquity Publications Ltd, 2016
RICHARD DAVIS. The Late Bronze Age spearheads of Britain (Prähistorische Bronzefunde 7). 2015. 267 pages, 163 colour and $19 \mathrm{~b} \& \mathrm{w}$ illustrations, 19 tables. Stuttgart: Franz Steiner; 978-3-515-11246-8 hardback $€ 78$.

Christopher Evans, Grahame Appleby \& SAm Lucy. Lives in land-Mucking excavations. Volume 1. Prehistory, context and summary. 2015. xvii+566 pages, numerous colour and b\&w illustrations. Oxford \& Havertown (PA): Oxbow; 978-1-78570-148-1 hardback $£ 40$.

JONNY GEBER. Victims of Ireland's great famine: the bioarchaeology of mass burials at Kilkenny Union Workhouse. xxiii+285 pages, numerous b\&w illustrations, tables. 2015. Gainesville: University Press of Florida; 978-0-8130-6117-7 hardback $\$ 84.95$.

Cheryl Green \& Roberta Gilchrist. Glastonbury Abbey: archaeological investigations 1904-79. 2015. $\mathrm{xxi}+501$ pages, numerous colour and $\mathrm{b} \& \mathrm{w}$ illustrations. London: Society of Antiquaries of London; 978-0-854313-00-6 hardback $£ 45$.

GWilym Hughes \& Ann WoOdward. The Iron Age and Romano-British settlement at Crick Covert Farm: excavations 1997-1998 (DIRFT Volume I). 2015. xiv +314 pages, numerous colour and $b \& w$ illustrations. Oxford: Archaeopress; 978-178491-208-6 paperback $£ 48$.

Robert MASEFIELD (ed.). Origins, development and abandonment of an Iron Age village. Further archaeological investigations for the Daventry international rail freight terminal, Crick \& Kilsby, Northamptonshire 1993-2013 (DIRFT Volume II). 2015. vi+324 pages, numerous colour and b\&w illustrations. Oxford: Archaeopress; 978-1-78491-218-5 paperback $£ 48$.

Catriona J. McKenzie, Eileen M. Murphy \& Colm J. Donnelly (ed.). The science of a lost medieval Gaelic graveyard (TII Heritage 2). 2015. $\mathrm{x}+219$ pages, numerous colour and $\mathrm{b} \& \mathrm{w}$ illustrations, CD-ROM. Dublin: Transport Infrastructure Ireland; 978-0-9932315-2-0 paperback $€ 25$.

PATRICIA SOUTHERn. Hadrian's Wall: everyday life on a Roman frontier. 2016. 430 pages, numerous colour and b\&w illustrations. Stroud: Amberley 978-1445640259 hardback $£ 25$.

\section{Byzantine, early medieval and medieval}

James H. Barrett \& Sarah Jane Gibbon (ed.). Maritime societies of the Viking and medieval world. 2015. xii+396 pages, numerous colour and b\&w illustrations. Leeds: Maney; 978-1-909662-79-7 hardback $£ 60$.

JUAN ANTONio Quirós CASTILlo \& SANTIAGO Castellanos García. Identidad y 
etnicidad en Hispania. Propuestas teóricas y cultura material en los siglos V-VIII (Documentos de Arqueología Medieval 8). 2015. 400 pages, numerous b\&w illustrations. Araba: Heritage and Cultural Landscapes Research Group; 978-84-9082-214-2 paperback $€ 36$.

Mette Svart Kristiansen, Else Roesdahl \& James Graham-Campbell (ed.). Medieval archaeology in Scandinavia and beyond: history, trends and tomorrow. 2015. 405 pages, numerous colour and b\&w illustrations. Aarhus: Aarhus University Press; 978-87-7124-378-9 hardback £41.50.

Alfonso Vigil-Escalera Guirado. Los primeros paisajes altomedievales en el interior de Hispania. Registros campesinos del siglo quinto d.C. (Documentos de Arqueología Medieval 7). 2015. 352 pages, numerous b\&w illustrations. Araba: Heritage and Cultural Landscapes Research Group; 978-84-9082-101-5 paperback $€ 24$.

\section{Historical and post-medieval archaeology}

Robin A. Beck, Christopher B. Rodning \& DAVID G. MOORE (ed.). Fort San Juan and the limits of empire: colonialism and household practice at the Berry site. 2016. $\mathrm{xxi}+426$ pages, several colour and b\&w illustrations. Gainesville: University Press of Florida; 978-0-8130-6159-7 hardback \$89.95.

Alasdair BROOKS (ed.). The importance of British material culture to historical archaeologies of the nineteenth century. 2015. xii+369 pages, $67 \mathrm{~b} \& \mathrm{w}$ illustrations, 18 tables. Lincoln: University of Nebraska Press; 978-0-8032-7730-4 hardback $\$ 90$ $\& £ 65$.

Charles R. Ewen \& Russell K. SkowroneK (ed.). Pieces of eight: more archaeology of piracy. 2016. xviii +318 pages, numerous b\&w illustrations.
Gainesville: University Press of Florida; 978-0-8130-6158-0 hardback \$39.95.

Roberto VAlCÁrCel Rojas. Archaeology of early colonial interaction at El Chorro de Maita, Cuba. xv+402 pages, numerous b\&w illustrations, tables. 2016. Gainesville: University Press of Florida; 978-0-8130-6156-6 hardback \$84.95.

\section{Heritage, conservation and museums}

John Boardman, Andrew Parkin \& Sally Waite. On the fascination of objects. 2016. xii+179 pages, numerous colour and b\&w illustrations. Oxford: Oxbow; 978-1-78570-006-4 hardback $£ 60$.

ANA LUISA SÁNCHEZ LAWs. Museum websites and social media: issues of participation, sustainability, trust and diversity (Museums and Collections 8). 2015. vi+203 pages, several b\&w illustrations. New York \& Oxford: Berghahn; 978-1-78238-868-5 hardback $\$ 85$.

Tiffany JenKInS. Keeping their marbles: how the treasures of the past ended up in museums - and why they should stay there. 2016. ix+369 pages, several b\&w illustrations. Oxford: Oxford University Press; 978-0-19-965759-9 hardback £25.

\section{Other}

DAVID GILMAN. Gate of the dead. 2016. xiii+448 pages. London: Head of Zeus; 978-1-78185-290-3 hardback $£ 14.99$.

Opuscula: Annual of the Swedish Institutes at Athens and Rome 8. 2015. 196 pages, numerous colour and b\&w illustrations. Stockholm: Editorial Committee of the Swedish Institutes at Athens and Rome; 978-91-977798-7-6 paperback $£ 52$. 